areas of heavy mononuclear cell infiltration. Lying free in some blood vessels were schistosome eggs. All but two of those seen were labelled, usually heavily, as were eggs passing through blood vessel walls or lying in the tissues, but with, as yet, practically no cellular reaction. All these eggs were very basophilic and lacked fully differentiated miracidia. Many mature eggs were seen in the centre of granulomas. None of these eggs were labelled, though host granuloma cells often were. The cellular infiltrate was also partly labelled. No labelled eggs were seen in the control material. Labelling in the injected anima] was confirmed by all three autoradiographic techniques.

It has therefore been shown that schistosome eggs can be labelled with tritiated thymidine and that labelling is confined to those being laid, or at least very young, at the time of injection, as judged by miracidial cytology, egg location, and size of the host reaction. This approach is applicable to the study of dynamics within the host of many other parasitic infections.

This investigation was supported by grants from the Rockefeller Foundation, World Health Organization and Tropical Medicine Research Board.

David J. Bradley

Department of Preventive Medicine,

Makerere College Medical School, Kampala, Uganda.

Received April 3, 1968.

' Warren, K. S., Amer. J. Trop. Med. Hyg., 10, 870 (1961).

${ }^{2}$ Andrade, Z. A., and Warren, K. S., Trans. Roy. Soc. Trop. Med. Hyg., 58. 53 (1964).

"Prata, A., Biópsia retal na esquistossomose, thesis, Serviço nacional de educaça sanitaria, Rio de Janeiro (1957).

4 Pellegrino, J., Oliveira, C. A., Faria, J., and Cunha, A. S., Amer. J. Trop. Med. Hyy., 11, 201 (1962).

${ }^{\circ}$ Moore, D. V., and Sandground, J. H., Amer. J. Trop. Med. Hyg., 5, 83। (1956). "Rogers, A. W., Techniques of Autoradiography, 104 (Flsevier, Amsterdam.

\section{Unusual Mode of Reproduction in a New Species of Polychaete}

A NEW species of Rhamphobrachium (Onuphidae: Polychaeta) has recently been discovered on the Victorian coast of southern Australia and is being described elsewhere by one of us. This new species shows a number of unusual features for the genus, apart from its mode of reproduction. There are nine species of Rhamphobrachium already described from various parts of the world and they are all deep water forms, ranging from 10 fathoms to 725 fathoms with the deeper habitats predominating. These species have all been described as being associated with a sandy or mud bottom from which they were easily extracted by dredging. The new species is littoral in habitat, being found just above low water mark in tubes in hard limestone (calcarenite) rock. Because of this unusual habitat this is the first member of the genus to be available for study on its biology and a full study of its reproductive biology is to begin soon. This is a preliminary report of the unusual features of its reproductive biology.

Most polychaetes have small eggs which are liberated into the plankton, where fertilization occurs and where the developing larva spends some time before metamorphosing into an adult. This new species is unusual in that it lays large yolky eggs into a special brood chamber partitioned off from the main tube and in which the entire development is undertaken until miniature adults are ready to emerge.

The sexes are separate and the reproductive organs seem to be confined to the posterior part of the body. When the worms are mature the males can be identified by the large irregularly shaped white patches visible through the body wall, while in the female, large, salmon coloured spherical eggs can be seen. The breeding season

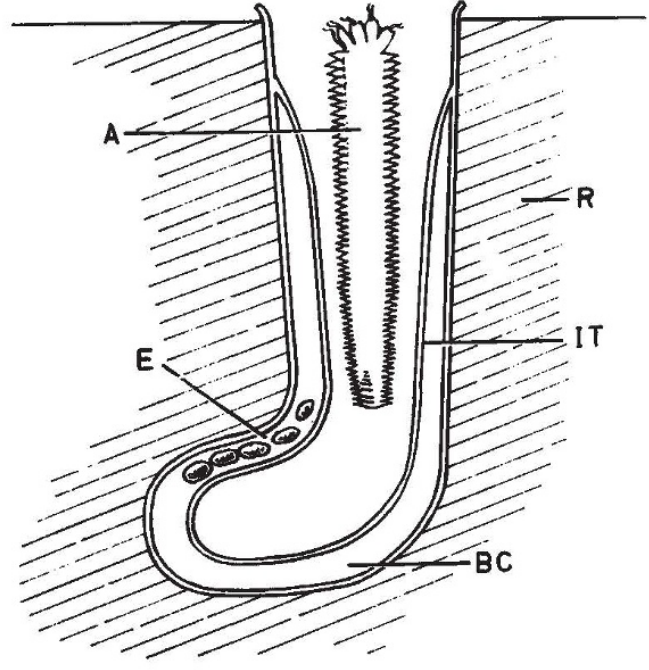

Vig. 1. Diagram showing the position of the brood chamber in relation to the living tube of the new Rhamphourachium species. A, Adult worm:
BC, brood chamber; E, position of eggs; IT, inner tube; R, limestone $\mathrm{BC}$, brood chamber; $\mathrm{E}$, position of egg.

(if one occurs at all) seems to be in the summer, for tubes with young present have been found in January and March and eggs and mature adults have been found in March. The brood chamber seems to be constructed by the worms laying down a second mucilaginous tubinside the normal tube, the space between the two becoming the brood chamber (Fig. 1). The exact method and location for fertilization is unknown, but it is possible that the male enters the female's tube, because there is sufficient space, and two worms were thought to have. been present in a single tube on one occasion, the sexes: unfortunately being unknown.

The number of eggs observed in the female and in the brood chamber varies from ten to twenty. The eggs in the brood chamber are spherical to ovoid, from $0.3 \mathrm{~mm}$ to $0.5 \mathrm{~mm}$ in diameter. The young found in the tubes are at a very early stage and contain obvious yolk supplies in their gut. One interesting observation is that the young in a single tube vary in size from large ones with very little yolk in their gut to very small ones with a great deal of yolk still present.

In one brood of sixteen young all taken from the same tube, the smallest had only seven segments visible and a great deal of yolk, while the largest had practically no yolk and had twenty-eight segments visible. There ar 105 adult segments. Assuming that the rate of development was approximately constant for all the young in the brood, then the range in sizes of the various young of the same brood suggests that laying is staggered over a period, and that there is external fertilization of the eggs in the tube.

This mode of reproduction, with large yolky eggs and the telescoping of the larval stages into the egg develop. ment, is referred to here as unusual. It may, however, be typical of the genus Rhamphobrachium and may be the usual method of reproduction for most deep water poly. chaetes.

Another small point of interest is the very common occurrence on this new species of what appears to be a small protozoan ectoparasite found chiefly on the gills and dorsal segments of the anterior half of the body.

We thank Mr R. Miller for drawing the diagram.

B. J. SмIтH

Invertebrate Department,

R. L. JENSt,

National Museum of Victoria,

Melbourne, Australia.

Received April 19, 1968. 